\title{
Professional Competency-Based Mathematics Learning Devices In The Mechanical And Automotive Engineering Program High School
}

\author{
1stRoli maizendra \\ Mathematics and Science Faculty \\ Universitas Negeri Padang \\ Padang, Indonesia \\ rolimaizendra10@gmail.com
}

\author{
$2^{\text {nd }}$ Armiati \\ Mathematics and Science Faculty \\ Universitas Negeri Padang \\ Padang, Indonesia
}

\begin{abstract}
This study discusses the development of professional competency-based mathematics learning tools in mechanical and automotive engineering expertise programs in class X Vocational High Schools (SMK). Learning tools developed in the form of Learning Implementation Plans (RPP) and Student Worksheets (LKPD). he development model used in this study is the Plomp model (Preliminary Research, Prototyping Phase, and Assessment Phase). However, in this study only reached the preliminary research stage. The subjects of this study were $X$ grade Vocational High School students in mechanical and automotive engineering programs. Based on the results of interviews that have been conducted to several teachers of SMK 1 Padang,it can be concluded that the mathematics learning tools commonly used by teachers are still general without giving differences and character in each of the expertise programs available to students, especially in mechanical and automotive engineering programs.
\end{abstract}

Keywords-Mathematics Learning Devices,Professional Competence,Preliminary Research.

\section{INTRODUCTION}

Vocational High School (Vocational School) is one of the institutions in the education unit that has the role of creating qualified and competent Human Resources (HR) in their fields. Quality human resources are ready-to-use workers, namely workers who demonstrate mastery of science, technology, and high skills followed by good morals, ethics and character. Jatmoko [1] stated that Vocational High Schools (SMK) are educational institutions that have the potential to prepare human resources that can be absorbed by the world of work, because the applicative theoretical and practical material has been given since entering vocational school in the hope that SMK graduates have the competence in accordance with world needs. work. Mulyasa [2] defines competence as mastery of a task, skill, attitude, and appreciation needed to support success. This means that competencies include the tasks, skills, attitudes, and appreciation that students must possess in order to carry out the tasks they have learned in school in accordance with the abilities needed by the workforce. While the profession relates to a job that is owned by someone. Profession is work carried out as a main activity to make a living and rely on expertise.

The National Education System Law [3] explains that Vocational High Schools are secondary education that prepares students especially to work in certain fields. Specific fields are areas that are selected and studied as long as students are in vocational education institutions. Vocational education is an education subsystem that specifically helps students in preparing themselves to enter employment (Law No. 20 of 2003).

The function of vocational education with K13 functions in a double way, namely as "acculturation" (adjustment) and "enculturation" (carrier of change). Therefore, vocational education is not only adaptive to change, but also must be anticipatory. In the process of implementing vocational education based on the existing K13 students are required to be able to think creatively and innovatively and the selfdevelopment they have must be issued to support learning. In learning in Vocational Schools after the entry of K13 can be seen from the delivery of existing material.

In learning in vocational schools, teachers must make an effort to implement the function of vocational education. The effort that can be done is to develop every potential that students have based on their fields of expertise, especially in mathematics learning. Mathematics is one of the compulsory subjects that must be given to students of vocational high school technology and nontechnology. For that, during the process of learning mathematics, the teacher should pay attention to the character of students by adjusting the material that has a relationship with the area of expertise of students, namely technology and engineering that can improve not only mathematics but also the competence of students in a skill program that is useful when students are already in the world of work.

Education in vocational schools consists of various professional competencies and expertise programs. Mechanical engineering and automotive engineering are part of several programs in the fields of technology and engineering expertise. Mechanical and automotive engineering in vocational schools aims to empower graduates who have the competence and expertise in their field with evidence of a certificate of expertise so that they can be accepted and directly involved in the world of work in accordance with market needs. Not only that, the graduates produced are expected to have a strong, polite, responsible, and able to communicate well and have a soul that can develop an entrepreneurial spirit in accordance with their expertise. 
For the sake of creating qualified and competitive SMK graduates in the world of work, there needs to be effort from various parties such as the government, private sector and schools, especially teachers to improve students' competencies in order to become a professional workforce. One of the efforts that can be done especially from the teacher as an educator is to increase the human resources of students when they graduate so that they can be accepted and worked in the world of work.

One form of effort that can be done is to improve the quality of education so that human resources are more qualified. The success of education is largely determined by learning in school. According to the Minister of Education and Culture [5] stated that the principle of ideal learning is when students can find out for themselves and learn based on various learning resources. Teachers as one of the actors in the education world must be able to transfer their knowledge and knowledge to students.

Mathematics is a compulsory subject that must be taught in vocational schools. According to the Minister of Education and Culture [6] stated that the objectives of high school / vocational high school mathematics learning that cover concept understanding, problem solving, reasoning ability, idea communication skills, have an appreciation of mathematics, have attitudes and behaviors that are in accordance with the values in mathematics and learning, doing motoric activities that use mathematical knowledge, as well as using simple teaching aids as well as the results of technology to conduct mathematical activities. Based on several objectives of learning mathematics in vocational schools, one of the final goals in learning mathematics is that students are able to solve a mathematical problem itself. The ability to solve problems is a general goal of teaching mathematics, meaning that mathematics can help in solving problems both in other subjects and in everyday life. Therefore, this problem solving ability is a general goal of mathematics learning.

Although mathematics is a compulsory subject that students must learning in vocational schools, in reality many vocational school students who do not like and are even afraid to learn mathematics. Students assume that mathematics learning is not interesting and not so important to learn. To respond to this, there must be action so that participants have motivation and desire to learn mathematics.

One effort that can be done by the teacher as an educator is by developing a mathematics learning tool. The tools that the teacher must have before teaching are the Learning Implementation Plans (RPP) and Student Worksheets (LKPD). According to Trianto [7] states that the learning implementation plan is a guide to the steps to be taken by the teacher in learning activities that are arranged in an activity scenario. Whereas RPP is also regulated in the Ministry of Education and Culture regulations [8] states that RPP is a plan for face-to-face learning activities for one or more meetings. With the RPP, the teacher has guidelines in carrying out the teaching and learning process. In addition, the RPP is prepared with the aim that the learning carried out can run systematically, effectively, fun and achieve the expected learning goals. The RPP that is used as a guideline for the implementation of learning by the teacher should be prepared by the teacher concerned and truly used as a guide in the implementation of learning.
In addition to RPP, the Student Worksheet (LKPD) is also needed to achieve the learning objectives. Ministry of National Education [9] Student Worksheet (student worksheet) are sheets containing tasks that must be done by students. Prayitno [10] stated that LKS is a means to convey concepts to students both individually and in small groups that contain instructions for carrying out various activities. Whereas Trianto [11] explained that "LKS is a guide for students who are used to conduct investigation or problem solving activities". In the process of mathematics learning, teachers are expected to be able to make LKPD in Vocational Schools in accordance with the professional competencies and expertise programs of students. LKPD that is in accordance with the students' expertise program provides a good influence in the learning process of students. With the existence of LKPD based on professional competence can increase learning motivation so that students are interested in learning mathematics. This happens because RPP and LKPD are developed directly related to their expertise programs so that they can increase the competency of students when they graduate from vocational high school and make participants become professional workers.

Based on the observations that researchers conducted in November to December 2017 at SMK 1 Padang and SMK 5 Padang, information was obtained that the interest and interest of students in learning mathematics was still not seen. This happens because students assume that mathematics is a difficult and not so important lesson to learn so that students are not serious when learning mathematics. This is evident because many of the students did not take the lessons seriously, did not do the exercises given by the teacher and they even talked to the other friends and some were in and out of class when the learning took place. The cause of the students' lack of seriousness in learning mathematics is that the teacher's learning tools are still general. The learning tools owned by the teacher do not have the character as a differentiator in each skill program, even the same as the devices owned by high school teachers. The low interest and motivation of students of SMK 1 Padang occurred because the devices developed by mathematics teachers had not been able to increase motivation and interest in learning mathematics.

Learning tools such as the Learning Implementation Plan (RPP) owned by the teacher have not provided learning designs that can create learning conditions to improve the ability of professional competence of students. RPP developed by the teacher does not provide an opportunity for students to improve professional competence in each skill program. Similar to RPP, the Student Worksheet (LKPD) used by the teacher in the teaching and learning process is also still general because the LKPD used is taken from the textbook questions and even LKPD sold by the publisher.

Based on research conducted by Hestu Tansil entitled "Development of mathematics learning tools based on professional cometency in vocational information and communication technology expertise" concluded that the developed learning tools were valid (RPP 3.49, LKPD 3.68), practical (RPP 86.16\%, LKPD $86.52 \%$ ), and effective.

\section{METHODS}

The research conducted in this research is development research. Borg and Gall [12] stated that development research is a research method used to develop or validate 
products used in education and learning. The research model used in this study is the Plomp development model. Plomp [10] states that the Plomp model consists of three stages, namely the initial investigation phase (preliminary research), the development or prototype (development or prototyping stage) phase, and the assessment stage. In the initial investigation phase (preliminary research) there are several activities carried out namely analyzing needs, curriculum analysis, concept analysis and analysis of students and teachers to collect data, analyze and identify problems that occur in learning as a basis for determining alternative solutions and product specifications needed according to the problem found.

\section{RESULTS AND DISCUSSION}

Needs analysis was conducted at SMK 1 Padang on 4-6 December 2017 by conducting observations and interviews to several mathematics teachers and students. On December 4, 2017 an observation was conducted on the learning device designed by the teacher in the form of RPP and LKPD. Based on observations obtained data that RPP designed by the teacher is in accordance with the provisions of the 2013 curriculum, but in practice it has not been implemented properly. The RPP is still general in nature which has not given a different character in each skill program. In mathematics learning activities, there are still many students who are not serious about learning. This can be seen from the activities of students who do not care about learning activities, students who talk to their next friends, go in and out during class hours, and many still do not do the assignments given by the teacher.

This cannot be allowed to happen continuously without any settlement. For this reason, interviews were conducted with mathematics teachers and students in order to find out the causes and needs of students so that a suitable solution was found so that the problem could be resolved immediately.

Based on the results of interviews of several teachers, information was obtained that the learning tools developed by the teacher were obtained from friends of profession. RPP and LKPD developed by teachers are still general without giving differences based on expertise programs so that they have not been able to attract the attention of students to study well. In learning activities, the teacher does not guide students to find material concepts. The teacher immediately provides material in the form of titles, formulas, sample questions and some practice questions that students must do.

Interviews were also conducted to several students majoring in mechanical engineering and automotive engineering to find out their views on mathematics subjects. From the results of the interview, information was obtained that in general students did not like learning mathematics. This is because students think that mathematics is not so important to learn because it does not provide benefits when they graduate and are in the world of work.

With students' dislike in learning mathematics, resulting in students not having motivation in learning and feeling not at home for longer. They prefer to study in productive subjects when compared to math lessons. Students are not interested in learning mathematics because they feel they have no relationship with productive subjects that are in accordance with the mechanical engineering and automotive engineering programs.

Of the many students who do not like mathematics, there are still some students who are happy and like math. But in general these students have difficulties in understanding application questions related to application in daily life.

Based on the results of the needs analysis, there are several findings obtained from the observations and interviews of mathematics teachers and vocational school students, namely (1) the lesson plans used by teachers do not have differentiation based on expertise programs, (2) LKPD used by teachers is still general and acquired from printing, (3) Learners prefer roductive lessons than mathematics, (4) Not able to solve the problems of alikasi (5) Learning activities and materials provided do not dance students.

Based on the findings from the results of the needs analysis, there needs to be improvements. One of the improvements that can be made from these findings is to improve learning and material activities. The context of the problem in the given mathematics material should be related to productive subjects such as in mechanical and automotive engineering.

Curriculum analysis was conducted to examine the 2013 curriculum on mathematics subjects and productive subjects used in vocational schools. This analysis is conducted to see the suitability of Core Competencies (KI) Basic Competencies (KD), Indicators of Achievement of Competencies (GPA) in mathematics and elective subjects in mechanical engineering and automotive engineering.

Concept analysis aims to determine the content and material of mathematics lessons needed in the learning device. In addition, this concept analysis determines the relationship between productive material in vocational high school engineering and automotive engineering study programs with mathematics that is the content of the learning tools that will be developed.

Based on Kepmendikbud 130 / D / KEP / KR / 2017, the mathematics material taught in odd semester is (1) Rank numbers, roots, and logarithms, (2) Equations and absolute value inequalities, (3) Linear equations of two variables, (4) Linear Program, (5) Arithmetic Series and Series, (6) Growth, decay, interest, and annuity. In mechanical engineering in the form of (1) mechanical engineering drawings, (2) basic mechanical engineering, (3) mechanical technology, technical mechanics and machine elements. Automotive Engineering with material (1) Drawing of automotive engineering, (2) Basic automotive technology, (3) Basic automotive workmanship.

Based on the results of interviews conducted on December 5, 2017, information was obtained that the mathematics material taught in class X SMK 1 Padang in semester 1 was based on the MGMP Padang teacher agreement, namely (1) Rank numbers, roots, and logarithms, (2) Equality and inequality absolute values, (3) Linear Equations of two variables, (4) Arithmetic Ranges and Series. Linear program material and growth, decay, interest, and annuity are not taught because they do not have benefits that can support the competencies of students after graduating and working on mechanical engineering and automotive engineering programs. 
Based on the results of the curriculum analysis conducted on the subject of mathematics and productive subjects in the field of mechanical and automotive engineering expertise can be seen in table 1 as follows:

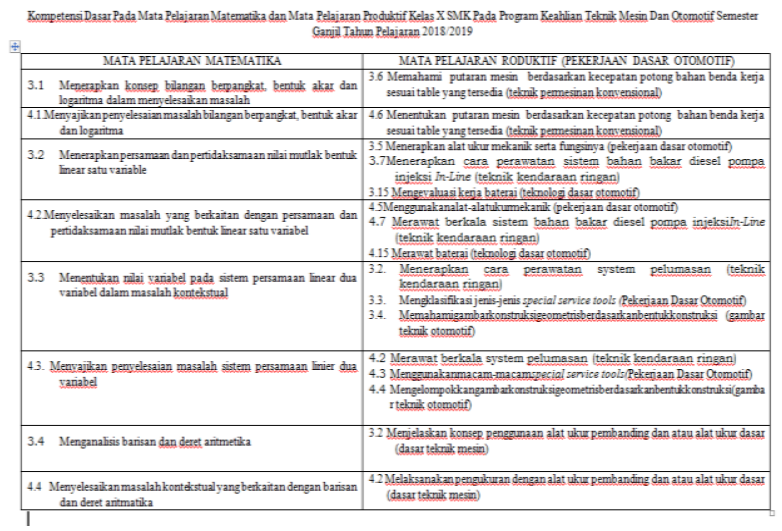

Afterobtaining $\mathrm{KD}$ in mathematics and productive subjects, then the basic competencies are translated into indicators of competency achievement and learning objectives in mathematics subjects and productive subjects. After elaborating, the $\mathrm{KD}$ is determined in productive subjects that can be applied in mathematics because not all $\mathrm{KD}$ in productive subjects that can be applied in mathematics.

Concept analysis is done to determine the mathematical material that will be studied in class X SMK in mechanical and automotive engineering. After the contents of the material are determined, then identify the concepts, detail, and systematically compile in determining the concept of problems related to the professional competence of students in the mechanical engineering and automotive engineering programs.

Based on observations and interviews on the analysis of students and teachers, obtained information, namely (1) Lack of seriousness of students in learning mathematics, (2) Students prefer to learn productive lessons than mathematics, (3) Students assume mathematics as a difficult subject and not so important to learn, (4) Difficulties of students in completing application questions from mathematics, (5) RPP owned by teachers is still general and can be used by all skill programs, (6) LKPD used by teachers has not attracted attention learners.

Based on information obtained from the results of the initial investigation (Preliminary Research), an attempt was made as a solution to overcome the problems that had been found. One solution that can overcome these problems is by developing a tool for learning mathematics based on professional competence in the mechanical and automotive engineering program.

The device is designed according to the needs of students, namely in addition to increasing the competence of students from mathematics but also can improve the professional competence of students that can be used when in the workforce. The RPP that was developed should be able to increase the motivation of students, and have a critical attitude, and be responsible.

LKPD is designed according to the needs of productive subjects in mechanical and automotive engineering programs. The context of the problems presented in the
LKPD is adjusted to the competence of the expertise that can be used when participants pass and are in the world of work.

\section{CONCLUSION}

Mathematics learning devices based on professional competence developed in this study only reached the preliminary research stage. The plomp model used in the research which consists of three stages, namely preliminary research, prototyping phase, and assessment phase is very helpful in developing learning tools for professional learning based on mathematics. With the existence of mathematics learning devices based on professional competencies, it is expected to increase the motivation and learning interest of students to learn mathematics because the devices are designed according to the competencies of the program of expertise of students so as to produce graduates who can be accepted in the world of work as qualified and professional workers. Students become more active in the learning process and are able to connect subject matter with everyday life or other sciences.

\section{REFERENCES}

V. Jatmoko. Dwi, "Relevansi Kurikulum SMK Kompetensi Keahlian Teknik Kendaraan Ringan Terhadap Kebutuhan Dunia Industri di Kabupaten Sleman”, Jurnal Pendidikan Vokasi 3(1):1-13,2013.

VI. Mulyasa. E, Menjadi Guru Profesional Menciptakan Pembelajaran Kreatif dan Menyenangkan, Bandung: Remaja Rosdakarya, (2005).

VII. Undang-Undang Republik Indonesia No 20 Tahun 2003 tentang Sistim Pendidikan Nasional

VIII. Armiati, Pengembangan Modul Matematika Berbasis Kompetebsi Profesi Pada Sekolah menengah Kejuruan Teknologi. Dirjen PT Depdiknas. Penelitian Hibah Bersaing: FMIPA-UNP. 2008.

IX. Peraturan Menteri Pendidikan dan Kebudayaan Republik Indonesia Nomor 103 Tahun 2003 tentang Standar Proses Pendidikan Dasar dan Menengah.

X. Peraturan Menteri Pendidikan dan Kebudayaan Republik Indonesia Nomor 58 Tahun 2014 tentang Standar Proses Pendidikan Dasar dan Menengah.

XI. Trianto, Mendesain Model Pembelajaran Inovatif-Progesif, Jakarta: Kencana Prenada Media Kelompok,2009.

XII. Peraturan Menteri Pendidikan dan Kebudayaan Republik Indonesia Nomor 22 Tahun 2016 tentang Standar Proses Pendidikan Dasar dan Menengah.

XIII. Depdiknas, Pengembangan Rencana Pelaksanaan Pembelajaran. Jakarta: Direktorat JendralManajemen Pendidikan Dasar dan Menengah, (2008).

XIV. [10] Prayitno. Edi, Materi Diklat Pedoman Pengembangan System Penilaian, Yogyakarta: FMIPA UNY, (2003).

XV. Trianto, Mendesain model pembelajaran inovatif-progresif: konsep, landasan, dan implementasinya pada Kurikulum Tingkat Satuan Pendidikan (KTSP), Jakarta: Kencana,(2011).

XVI. Borg. W.R. ., Gall. M.D, Educational research an introduction.(4th ed). New York: Longman Inc,(1983).

XVII. Akker. J. V., Plomp. Tjeerd, Educational Development in Developing Countries Dalam Skutsch, Margaret M, Opda, J. Hans M. And Nordholt, Nico G Schulte (Eds.), TowardsSustainable Development, Enschede: Tecnology and Development Group University of Twente, 1994. 